\title{
Paleoecology and paleobiogeographic patterns of mid-Holocene mollusks from the Beagle Channel (southern Tierra del Fuego, Argentina)
}

\author{
Sandra Gordillo ${ }^{1}$, Jorge Rabassa ${ }^{2}$, Andrea Coronato ${ }^{2}$ \\ ${ }^{I}$ Consejo Nacional de Investigaciones Cientificas, Centro de Investigaciones Paleobiológicas (CIPAL), Universidad Nacional de \\ Córdoba. Av. Vélez Sársfield 299, X5000JJC Córdoba, Argentina. \\ sgordillo@efn.uncor.edu \\ ${ }^{2}$ Consejo Nacional de Investigaciones Cientificas, Centro Austral de Investigaciones Cientificas (CADIC, CONICET), C.C. 92, 9410, \\ Ushuaia, Tierra del Fuego, Argentina. \\ jrabassa@gmail.com; acoro@cadic.gov.ar
}

\begin{abstract}
As the Beagle Channel lies between the Atlantic and the Pacific oceans, this is a critical region for the interpretation of faunal distributions in the Magellan Region. This work proposes a paleoenvironmental interpretation of the Holocene, inferred from malacological data. The development of different local benthic paleocommunities during the mid-Holocene is associated with the diversity of habitats inside this channel. The analysis of records of Venus antiqua and Ensis macha through time and their geographic links to ecological factors showed that these taxa are typical elements of the cold-temperate seas throughout the Magellan Region, showing a similar range of distribution and paleodistribution. The presence of these taxa in life position (AMS ${ }^{14} \mathrm{C}$ of $6,276 \pm 41$ years BP) suggests that during the mid-Holocene the Beagle Channel was a path for dispersion of these taxa between the two oceans. Whether Venus antiqua and Ensis macha are Pleistocene survivors or Holocene migrants is herein discussed. In the future, integrated cross-disciplinary studies will be necessary for a better understanding of the biogeographic relationships among magellanic mollusks.
\end{abstract}

Keywords: Paleoecology, Mollusca, Holocene, Tierra del Fuego.

RESUMEN. Paleoecología y patrones paleobiogeográficos de moluscos del Holoceno medio del Canal Beagle (sur de Tierra del Fuego, Argentina). El Canal Beagle es una región crítica para la interpretación de las distribuciones faunísticas en la Región Magallánica, ya que representa una conexión entre los océanos Atlántico y Pacífico. Sobre la base de datos malacológicos, este trabajo propone una interpretación paleoambiental para el Holoceno. El desarrollo de diferentes paleocomunidades bentónicas locales durante el Holoceno medio se asocia a la diversidad de hábitats dentro del canal. El análisis de los registros de Venus antiqua y Ensis macha a través del tiempo, y sus vínculos geográficos con factores ecológicos, indicó que estos dos taxones son elementos típicos de los mares frío-templados de la Región Magallánica, exhibiendo un patrón similar de distribución y paleodistribución. La presencia de estos taxones en posición de vida (AMS ${ }^{14} \mathrm{C}$ de 6,276 \pm 41 años AP) sugiere que durante el Holoceno medio el Canal Beagle constituyó una vía de dispersión de taxones entre los dos océanos. Respecto a su procedencia, se discute la factibilidad de que estos taxones sean sobrevivientes del Pleistoceno o inmigrantes del Holoceno. En el futuro, serán necesarios más estudios interdisciplinarios integrados para lograr una mejor comprensión de las relaciones faunísticas de los moluscos magallánicos. 


\section{Introduction}

The Beagle Channel $\left(54^{\circ} 53^{\prime} \mathrm{S}, 67^{\circ}-68^{\circ} \mathrm{W}\right)$ is located at the southernmost extreme of South America (Fig. 1), being part of an 'austral archipelago region' which goes from the Chiloé Island $\left(42^{\circ} \mathrm{S}\right)$ to Cape Horn $\left(55^{\circ} \mathrm{S}\right)$. This long archipelago has historically experienced the combined effects of tectonic activity, glaciers and climatic processes. Considering the fact that the Beagle Channel lies between the Atlantic and the Pacific oceans, this is a critical region for the interpretation of faunal distributions in the Magellan Region.

During the Quaternary the southern tip of South America was affected by several glaciations which might have excluded much of the benthic marine fauna inhabiting this region, with the consequent interruption of the connection between the two oceans. In that context, fossil marine mollusks which have been recovered from interglacial and postglacial Quaternary deposits can be used to follow periods of interchange and colonization between the Atlantic and the Pacific oceans.

It is known that the survival of a species over time or in a given geographical area often depends upon its ability to disperse. On the other hand, Valdovinos et al. (2003) recognized the importance of regional processes (i.e., geomorphological heterogeneity) in affecting global biogeographic patterns and increasing local diversity of mollusks.
Concerning glaciations, Crame (1996) suggests that one species could have survived repeated glacial advances over the past 40 million years by using some form of refugium. Thus, available data show that current biogeographic patterns are the result of a combination of biological factors, geomorphology and historical events which would have influenced the distribution of the species.

With regard to paleoecology, despite the bias in preservation (i.e., the loss of soft body taxa, post burial taphonomic processes), Quaternary mollusk assemblages retain useful information about the life habits and habitats of the marine benthos from which they are derived (Aitken, 1990). Previous available information showed that mollusks from this region provide a key for the reconstruction of paleocommunities and the evaluation of changes in faunal composition during the Holocene (Gordillo et al., 2005).

The objective of this work is to analyze the paleobiogeographical patterns of distribution of the bivalves Venus antiqua and Ensis macha in southern South America, and to examine the mid-Holocene records from the Beagle Channel in a paleoecological and paleoenvironmental context. This contribution is part of a cooperative research project between the Centro de Investigaciones Paleobiológicas (CIPAL, Universidad Nacional de Córdoba) and the Laboratorio de Geología del Cuaternario (CADICCONICET, Ushuaia), in Argentina.
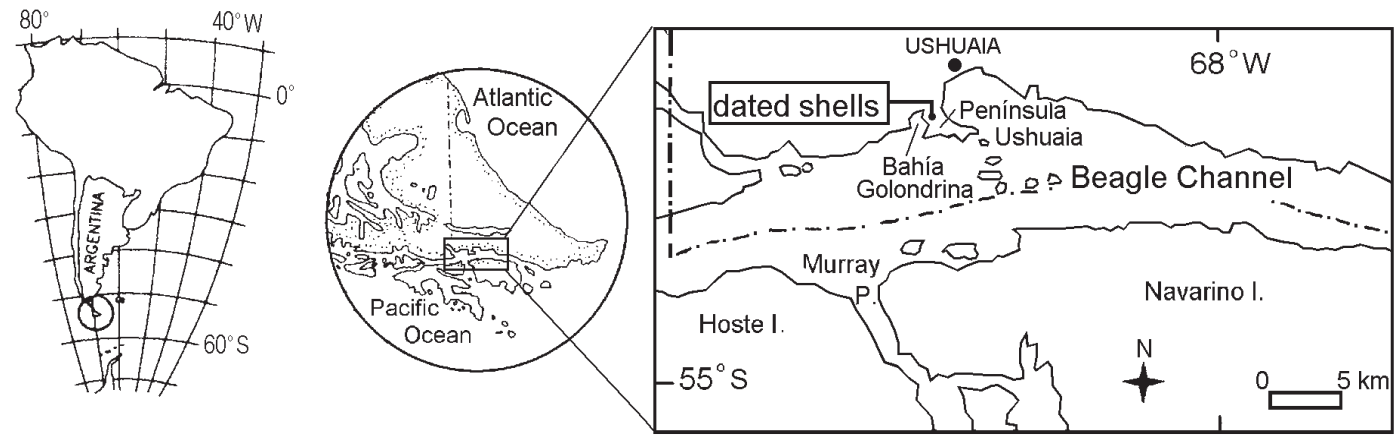

FIG. 1. Map of the studied region showing the Beagle Channel area and the location of Bahía Golondrina. 


\section{Geological Setting and the Main Quaternary Events}

The Beagle Channel is a drowned glacial valley $5 \mathrm{~km}$ wide and $180 \mathrm{~km}$ long in a western-eastern trend located in the seismotectonically active area of the Fuegian Andes, which was glaciated in at least two major episodes during the middle and late Pleistocene (Rabassa et al., 2000). The Last Glacial Maximum (LGM) was attained sometime around 25-24 ka BP (Kaplan et al., 2004) and the ice recession of the Beagle Glacier began sometime before $14.7 \mathrm{ka} \mathrm{BP}$ (Heusser, 1998). After these episodes, geomorphologic and stratigraphic evidence shows that the area was occupied by glaciolacustrine and glaciofluvial environments (Heusser, 1989; Rabassa et al., 2000). Freshwater was gradually replaced by seawater in the early Holocene, and the marine environment was then fully established in the Beagle Channel around 8,000-7,000 years ago, with a transgressive episode peaking around 6,000 years ago leaving scattered marine deposits in both northern and southern Beagle Channel coasts (Porter et al., 1984; Rabassa et al., 1986; Gordillo et al., 1992).

\section{Water Masses}

The Beagle Channel is a semi-closed basin with relatively shallow and constrained entrances (Antezana, 1999) and estuarine dynamics (Isla et al., 1999).

The large-scale oceanic surface circulation is controlled by the Antarctic Circumpolar Current (ACC), which transports cold, subantarctic water towards Chile. Off southern Chile (at around $43^{\circ} \mathrm{S}$ ) the ACC sends a branch, the Cape Horn Current, southwards. It passes around the continent through the Drake Passage and joins the Malvinas (Falkland) Current on the Atlantic side of South America, influencing both the eastern and western coasts.

A medium-scale hydrographic feature joining the subantarctic water of the Fuegian Archipelago is the input of a high fresh water supply originating from the melting of resident glaciers, high precipitation and river runoff.

\section{Material and Methods}

The Bahía Golondrina site is located on Península Ushuaia (Fig. 1) and is characterized by marine deposits at different elevations from +2 to +10 m (Urien, 1968; Gordillo, 1990a). Shells were collected from this site when they became exposed during the construction of a road to the Ushuaia international airport. A $125 \mathrm{dm}^{3}$ bulk sediment sample containing mollusks was obtained from a grey siltysand section at +2 meters above sea level (Gordillo, 1999). In the field, the specimens were counted and a sub-sample $(\mathrm{n}=20)$ was randomly collected from the entire sample. Some specimens are housed in the Centro de Investigaciones Paleobiológicas (CIPAL), Universidad Nacional de Córdoba (Argentina) under prefix CEGH-UNC 22209 to 22210.

The dating of this deposit was carried out on paired valves of the fragile shells of Ensis macha found in life position, an atypical situation with respect to other fossil mollusk assemblages along the Beagle Channel, which normally consist of transported mollusk assemblages (Gordillo et al., 1992). A radiocarbon date on this sample was obtained with AMS ${ }^{14} \mathrm{C}$ techniques at the NSF-Arizona AMS Laboratory (University of Arizona).

The ecological characterization of these taxa and their patterns of distribution are based on their equivalent living counterparts. A correlation of the Bahía Golondrina site with other previously studied sections of similar age (i.e., the Río Varela and Lago Roca sites; see references in Gordillo et al., 1993, 2005 and Coronato et al., 1999) contributed to the understanding of the environmental conditions during the Holocene transgression.

In addition, previous paleontological data for each species was compiled from different authors (i.e., Carcelles, 1944; Feruglio, 1950; Richards and Craig, 1963; Figueiras, 1967; Herm in Osorio et al., 1983; Cionchi, 1987; Pastorino, 1989, 2000; Gordillo, 1992; Ortlieb et al., 1991, 1994; Valdovinos, 1996; Frassinetti, 1997; del Río et al., 1998; Guzmán et al., 2000; Ortlieb et al., 2003; Aguirre, 2003; Aguirre et al., 2005, 2006; Cárdenas-Mancilla and Gordillo, 2006).

\section{Remarks on Systematics of Venus Antiqua}

The generic and subfamiliar assignment of $\mathrm{Ve}$ nus antiqua has been debated for a long time and is still under discussion. Some authors place it in Protothaca, or in Ameghinomya. However, on the basis of shell characters, it differs from species of Protothaca in its shape and in the prominence of its external sculpture (Beu, 2004); and it differentiates 
from species of Ameghinomya in having a nodular anterior lateral tooth in the left valve (Osorio et al., 1983). Beu (2004) also noted that Venus antiqua shell resembles that of Austrovenus stutchburyi from New Zealand. Nonetheless, the use of traditional shell-based characters alone appears to be questionable for resolving phylogenetic relationships of this group. In a recent molecular analysis within the family Veneridae, Kappner and Bieler (2006) found that this morphotype (i.e., with a lateral tooth) falls into the Venerinae s. novo clade. Therefore, these authors concluded that a revision of this enigmatic species is necessary. In the meantime, and taking into account the subfamiliar assignement by Kappner and Bieler (2006), we follow Osorio et al. (1983) and we refer to this species as Venus.

\section{Autoecology}

Two taxa in life position were recovered from the studied site: the razor clam Ensis macha (Molina, 1782) and the striped clam Venus antiqua (King and Broderip, 1832). These two species are dominant members of the shallow-water, soft-bottom communities of the Chilean coast zone (Urban, 1996), and they are within the 10 commercially most important species in Chile (Reid and Osorio, 2000).

Ensis macha (Fig. 2A) inhabits shallow subtidal soft bottoms along its area of distribution. This is a filter feeder which lives deeply buried in the sediment, favored by its shape and large foot (Urban, 1994a). It can be found on coarse sandy sediments or silty sands between 2 and $50 \mathrm{~m}$ depth (Ramorino, 1968; Urban, 1994a; Guzmán et al., 1998). In relation to the reproductive cycle, Ensis macha is a planktotrophic species which spawns either in the cold or the warm seasons (Avellanal et al., 2002; Barón et al., 2004).

The other bivalve, Venus antiqua (Fig. 2B) is a filter feeder which lives semi-infaunaly or infaunaly on silty-sand to stony bottoms from the intertidal zone to $40 \mathrm{~m}$ depth (Ramorino, 1968; Clasing et al., 1994; Urban, 1994a; Urban and Tesch, 1996; Reid and Osorio, 2000). Venus antiqua feeds on plankton and organic detritus, and also exhibits annual reproductive cycles with long spawning (Verdinelli and Schuldt, 1976; Lozada and Bustos, 1984).

Both species display variations in their reproductive cycles, which may be associated with changes in salinity and temperature affecting the coastal areas. They are able to develop under normal to lower salinity (of 21-27\%; Reid and Osorio, 2000) and tolerate a temperature range from $4^{\circ}$ to $20^{\circ} \mathrm{C}$ (Urban, 1994b).

\section{Living Distribution and Fossil Occurrences}

Ensis macha and Venus antiqua are typical elements of the Magellan Province, exhibing a wide area of distribution within the Pacific and the Atlantic oceans (Fig. 3, Table 1). The Magellan Province is a U-shaped, wide, cold-temperate region, comprising both sides of southern South America between $56^{\circ} \mathrm{S}$ to about $40^{\circ}-42^{\circ} \mathrm{S}$. Ensis macha lives from $55^{\circ} \mathrm{S}$ to $40^{\circ} \mathrm{S}$ along the Atlantic, but along the Pacific it penetrates into the peruvian waters to about $23^{\circ}$ (Osorio et al., 1979; Guzmán et al., 1998; Lasta et al., 1998; Barón et al., 2004). Venus antiqua also inhabits the Beagle Channel, and extends its range of distribution along the Pacific coast to Callao, in Peru, but also along the Atlantic coast to southern Brazil, penetrating the Argentinean Province (Ríos, 1994; Urban and Tesch, 1996; Reid and Osorio, 2000).

Brattström and Johanssen (1983) discuss the factors that favor and impede distribution in chilean waters. They consider that both, the direction and the great extension of the oceanic currents from south to north or north to south, parallel to the coast, favor passive distribution over long distances. The direction of the Cape Horn Current and the similar hydrographic conditions on both sides of the tip of South America make it likely that 'Pacific or Chilean' species will be found on the Atlantic side. Currents of different depths and directions may also play a role in larval distribution, since many larvae migrate vertically. Where currents meet, larvae can also be transferred passively from one current system to another by vertical and horizontal eddies; tidal currents and waves may facilitate spreading, both with and against the main ocean currents (Brattström and Johanssen, 1983). Thus, theoretically, larvae from the Pacific may be transported by the Cape Horn Current, farther south than the Beagle Channel, some even into the Atlantic.

At present, both taxa are extant species in the Beagle Channel and this region appears to be their southernmost geographical distribution. However, it is noted that both of them are apparently scarce in modern communities of Tierra del Fuego. For example, in the Magellan Strait, Venus antiqua and 


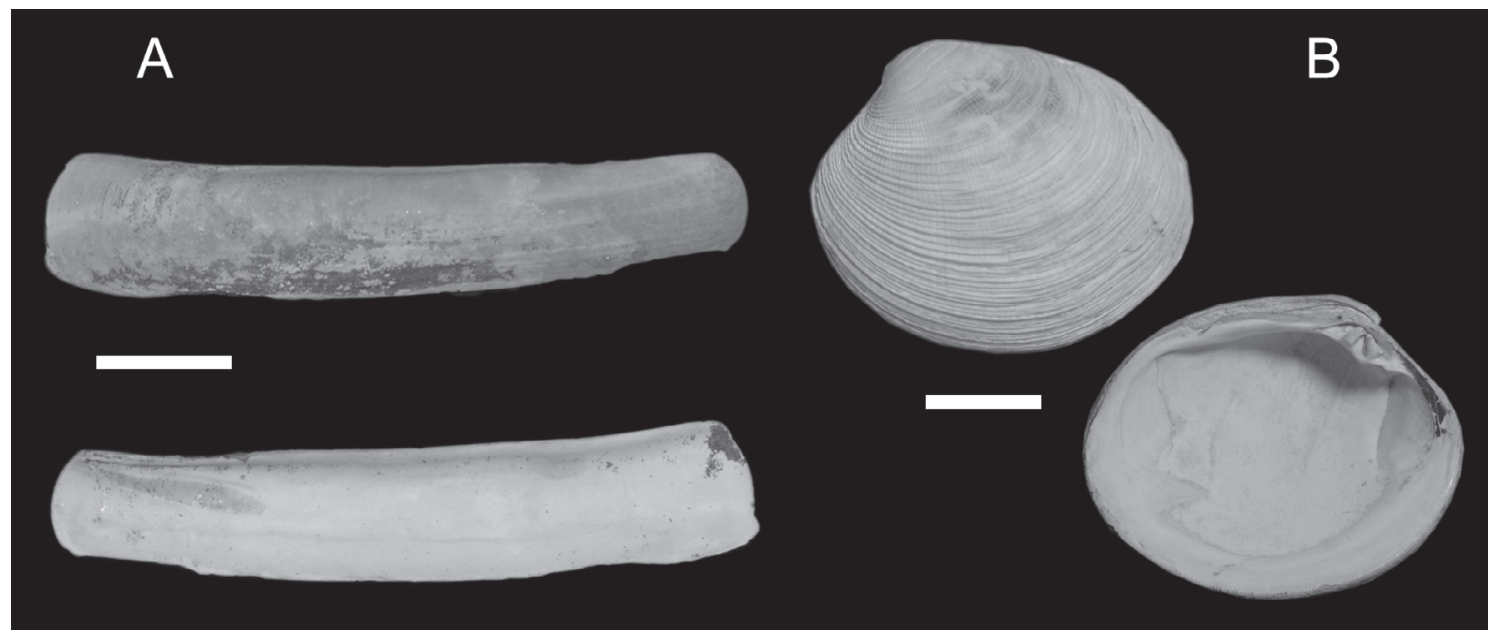

FIG. 2. A. Ensis macha (Molina), external and internal lateral views of right valve, CEGH-22209, Bahía Golondrina site, Beagle Channel; B. Venus antiqua (King and Broderip), external and internal lateral views of left valve, CEGH-22210, Bahía Golondrina site, Beagle Channel. Scale bar $=20 \mathrm{~mm}$.

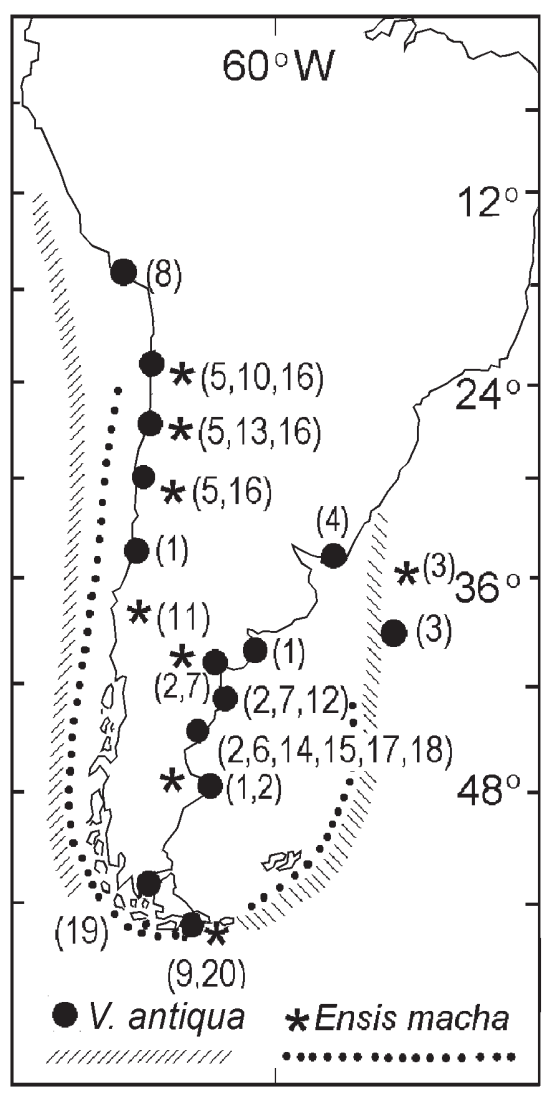

FIG. 3. South American map showing areas of present distribution of Ensis macha (dotted line) and Venus antiqua (slashed line) and locations of their fossil records (references of numbers in table 1).
Ensis macha were not mentioned alive between the Primera and Segunda Angostura sector (Ríos et al., 2003). Di Gerónimo et al. (1991) did not find these taxa when they sampled other Magellan Strait stations between 80 and $630 \mathrm{~m}$, and only Urban and Tesch (1996) collected Venus antiqua during low tide from San Juan $\left(53^{\circ} 40^{\prime} \mathrm{S}\right)$, a bay located about $60 \mathrm{~km}$ south of Punta Arenas. This scarcity may be attributed to a variety of factors: patchy distribution, sampling bias, preservation potential and/or accumulation of shells on the marine seafloor.

Although the Atlantic entrance to the Magellan Strait seems to be a natural barrier to the distribution of many species (Stuardo, 1964), the Beagle Channel probably does allow the dispersal of many species which have been recorded within or near it, and environmental constrains within this channel, such as low depths and low salinities, do not appear to represent barriers.

The occurrence of these taxa in the fossil record is presented in figure 3. Both taxa exhibit widespread Quaternary distribution along the Atlantic and the Pacific coasts of southern South America. Tertiary records appear more isolated and in some cases they should be treated with caution. For example, Frassinetti (1997) mentioned the finding of Ensis specimens from Pliocene strata in Guafo Island ( $\left.43^{\circ} 37^{\prime} \mathrm{S}\right)$, southern Chile, but their preservation state prevents their assignation as Ensis macha. This lack of accurate data makes it difficult 
TABLE 1. THE FOSSIL RECORD OF ENSIS MACHA AND VENUS ANTIQUA INDICATED IN THE MAP (FIG. 3).

\begin{tabular}{|c|c|c|c|c|}
\hline Ref. & Fossil record & Geological age & Locality, Region & Source \\
\hline 1 & Venus antiqua & $\begin{array}{l}\text { Cenozoic (Araucaniano, } \\
\text { Belgranenese, } \\
\text { Querandinense, Preque- } \\
\text { quense, Navidense) }\end{array}$ & $\begin{array}{l}\text { Puerto Belgrano }\left(38^{\circ} 53^{\prime} \mathrm{S}\right) / \\
\text { Puerto Deseado }\left(48^{\circ} \mathrm{S}\right) \\
\text { Argentina. Navidad }\left(34^{\circ} \mathrm{S}\right) \text {, } \\
\text { Central Chile }\end{array}$ & Carcelles (1944) \\
\hline 2 & $\begin{array}{l}\text { Ensis macha, } \\
\text { Venus antiqua }\end{array}$ & Quaternary & $\begin{array}{l}\text { Patagonia }\left(40 \text { to } 46^{\circ} \mathrm{S}\right) \text {, } \\
\text { Argentina }\end{array}$ & Feruglio (1950) \\
\hline 3 & $\begin{array}{l}\text { Ensis macha, } \\
\text { Venus antiqua }\end{array}$ & $\begin{array}{l}\text { Pleistocene } \\
\text { Pleistocene }\end{array}$ & $\begin{array}{l}\text { Off Uruguay }\left(34^{\circ} 47^{\prime} \mathrm{S}\right) \\
55 \mathrm{~m} \text { depth. Atlantic Ocean } \\
\left(37^{\circ} 38^{\prime} \mathrm{S}, 38^{\circ} 38^{\prime} \mathrm{S} ; 39^{\circ} 02^{\prime} \mathrm{S}\right)\end{array}$ & Richards and Craig (1963) \\
\hline 4 & Venus antiqua & Quaternary & $\begin{array}{l}\text { Punta Carretas, Montevideo, } \\
\text { Uruguay }\end{array}$ & Figueiras (1967) \\
\hline 5 & Venus antiqua & $\begin{array}{l}\text { Pliocene } \\
\text { Pleistocene, Holocene }\end{array}$ & $\begin{array}{l}\text { Chañaral de Azeitunas }\left(30^{\circ} \mathrm{S}\right) \\
\text { Hornito, Mejillones, } \\
\text { Caldera, La Serena, Tongoy } \\
\left(23 \text { to } 30^{\circ} \mathrm{S}\right)\end{array}$ & $\begin{array}{l}\text { Herm (1969) in Osorio } \\
\text { et al., } 1983\end{array}$ \\
\hline 6 & Venus antiqua & Pleistocene, Holocene & $\begin{array}{l}\text { Bahía Bustamante and Caleta } \\
\text { Malaspina }\left(45^{\circ} \mathrm{S}\right) \\
\text { Patagonia }\end{array}$ & Cionchi (1987) \\
\hline 7 & Venus antiqua & Holocene & $\begin{array}{l}\text { San Antonio O., Pla. Valdés, } \\
\text { Madryn }\left(40^{\circ} \text { to } 42^{\circ} \mathrm{S}\right) \text {, } \\
\text { Patagonia }\end{array}$ & Pastorino (1989) \\
\hline 8 & Venus antiqua & Late Pleistocene & $\begin{array}{l}\text { San Juan-Marcona }\left(15^{\circ} 30^{\prime} \mathrm{S}\right) \text {, } \\
\text { Perú }\end{array}$ & Ortlieb et al. (1991) \\
\hline 9 & Venus antiqua & Holocene & $\begin{array}{l}\text { Archipiélago Cormoranes, } \\
\text { Beagle Channel }\end{array}$ & Gordillo (1992) \\
\hline 10 & $\begin{array}{l}\text { Ensis macha, } \\
\text { Venus antiqua }\end{array}$ & Late Pleistocene & $\begin{array}{l}\text { Antofagasta area }\left(22^{\circ} 47^{\prime} \text { to } 23^{\circ}\right. \\
\left.47^{\prime} \mathrm{S}\right)\end{array}$ & Ortlieb et al. (1994) \\
\hline 11 & Ensis macha & Plio-Pleistocene & Tubul $\left(36^{\circ} \mathrm{S}\right)$, central Chile & Valdovinos (1996) \\
\hline 12 & Venus antiqua & Miocene & $\begin{array}{l}\text { Puerto Pirámide }\left(42^{\circ} \mathrm{S}\right) \text {, in Pla. } \\
\text { Valdés, Patagonia. }\end{array}$ & Del Río et al. (1998) \\
\hline 13 & $\begin{array}{l}\text { Ensis macha, } \\
\text { Venus antiqua }\end{array}$ & $\begin{array}{l}\text { Pleistocene } \\
\text { Pliocene to Recent }\end{array}$ & $\begin{array}{l}\text { Caldera }\left(27^{\circ}-28^{\circ} \mathrm{S}\right) \text {, northern } \\
\text { Chile }\end{array}$ & Guzmán et al. (2000) \\
\hline 14 & Venus antiqua & Holocene & Camarones $\left(45^{\circ} \mathrm{S}\right)$, Patagonia & Pastorino (2000) \\
\hline 15 & Venus antiqua & Pleistocene, Holocene & Golfo San Jorge, Patagonia & Aguirre (2003) \\
\hline 16 & Ensis macha & Early Pleistocene & $\begin{array}{l}\text { Mejillones }\left(23^{\circ} \mathrm{S}\right) \text {, Caldera } \\
\left(27^{\circ}-28^{\circ} \mathrm{S}\right) \text { and La Serena } \\
\left(30^{\circ} \mathrm{S}\right), \text { northern Chile }\end{array}$ & Ortlieb et al. (2003) \\
\hline
\end{tabular}


Table 1 (continued).

\begin{tabular}{|c|c|c|c|c|}
\hline Ref. & Fossil record & Geological age & Locality, Region & Source \\
\hline 17 & Venus antiqua & Pleistocene, Holocene & Bahía Bustamante, Patagonia & Aguirre et al. (2005) \\
\hline 18 & Venus antiqua & Pleistocene, Holocene & Vera-Camarones, Patagonia & Aguirre et al. (2006) \\
\hline 19 & Venus antiqua & Holocene & $\begin{array}{l}\text { Strait of Magellan }\left(52^{\circ} \mathrm{S}-53^{\circ} \mathrm{S}\right) \text {, } \\
\text { southern Chile }\end{array}$ & $\begin{array}{l}\text { Cárdenas-Mancilla } \\
\text { and Gordillo (2006) }\end{array}$ \\
\hline 20 & $\begin{array}{l}\text { Ensis macha, } \\
\text { Venus antiqua }\end{array}$ & Holocene & $\begin{array}{l}\text { Beagle Channel }\left(54^{\circ} 49^{\prime} \mathrm{S}\right) \text {, } \\
\text { Argentina }\end{array}$ & This work \\
\hline
\end{tabular}

to determine the migration direction. However, their age and pattern of distribution show that both taxa are Tertiary elements that participated in the interchange between the Atlantic and the Pacific oceans via southern South American seas. In the Beagle Channel there is also a second group of taxa (the Quaternary elements), mostly composed of micromollusks, which exhibit Antarctic affinities (Gordillo et al., 2005). Coming back to Ensis macha and Venus antiqua, when comparing their fossil distribution with the distribution of their living counterparts, they maintain a similar pattern along both sides of the South American coasts. It can be interpreted that these taxa evolved during the Plio-Pleistocene and migrated and extended their areas of distribution as connecting seaways formed. They may have crossed into southern waters during the Plio-Pleistocene, and much later during the Pleistocene and/or the Holocene. During migration, they probably occupied newly vacant areas formed during deglaciation. These new habitats were colonized by new communities formed by immigration of species living in any location with geographic access to these sites.

As fossils, their maximum northward extension corresponds to a middle Pleistocene interglacial episode (Marine Isotopic Stage 11; Ortlieb et al., $2003)$, recorded in northern Chile $\left(23^{\circ} \mathrm{S}\right)$. The new records on the northern coast of the Beagle Channel constitute the southernmost fossil record for both taxa.

The poor representation of Ensis macha in the fossil record (in comparison with Venus antiqua) may be due to ecological reasons (i.e., patchy distribution), but it is also plausible that it is due to low preservation potential of this taxon; the Ensis macha shell is thin and fragile; while, Venus antiqua is a thick-shelled species, which favors its preservation as a fossil.

\section{Paleoecology and Paleoenvironment Recons- truction}

A combination of neontological, paleontological and sedimentological data was used to reconstruct the paleoecology of the macrofossil assemblage from the Bahía Golondrina site.

Macrofossils from this site were found in life position (authochtonous assemblage). The Ensis sample used for dating gave a radiocarbon age of $6,276 \pm 41$ years BP (AA 62801) by AMS ${ }^{14} \mathrm{C}$. Life position specimens and the absence of sedimentary structures could be explained by a rapid accumulation process, probably caused by regional storms at the age of deposition. Figure 4 represents one hypothetical benthic macrofaunal paleocommunity characterized by the presence of green algae and macroinvertebrates such as Annelida (Polychaeta), Anthozoa (ceriantharia), Mollusca (bivalves) and Crustacea (Decapoda), among others. This reconstruction is based on both our fossil findings at the Bahía Golondrina site and additional ecological information; i.e., observations on benthic communities living in the Beagle Channel and data provided by Escofet et al. (1978), who described a similar modern macrofaunal Venus-Ensis assemblage at $41^{\circ} \mathrm{S}$ in Patagonia.

To improve understanding of the relationship between this site at $+2 \mathrm{~m}$ a.s.l. and the environmental conditions during the Holocene transgression, an 
analysis with two other sites of similar age, the Río Varela site, located $50 \mathrm{~km}$ east, and the Lago Roca site, $20 \mathrm{~km}$ west (Table 2), was carried out.

Difference in altitude among these sites would be explained by seismotectonic activity (Scotia Plate domain) and glacioeustatic processes affecting the whole Fuegian Andes region. Along the Beagle Channel, the Holocene tectonic uplifting reached its maximum level on the western sector of this channel, decreasing toward the east.

Taphonomic analysis and taxonomy of these assemblages support the distinction of different local mollusk assemblages. The fossil assemblages from the Río Varela and Lago Roca sites were transported after their death (allochtonous assemblages). This resulted in more diverse assemblages dominated by infaunal taxa (e.g., Retrotapes, Tawera, Mulinia) intermixed with some epifaunal elements (e.g., mytilidae, Nacella, Trophon, Xymenopsis). As it happens today in the Beagle Channel, the development of different local paleocommunities appears to be associated with a complex mosaic of microhabitats. The presence of hard (e.g., rocky intertidal) and soft areas (e.g., sandy beaches) are

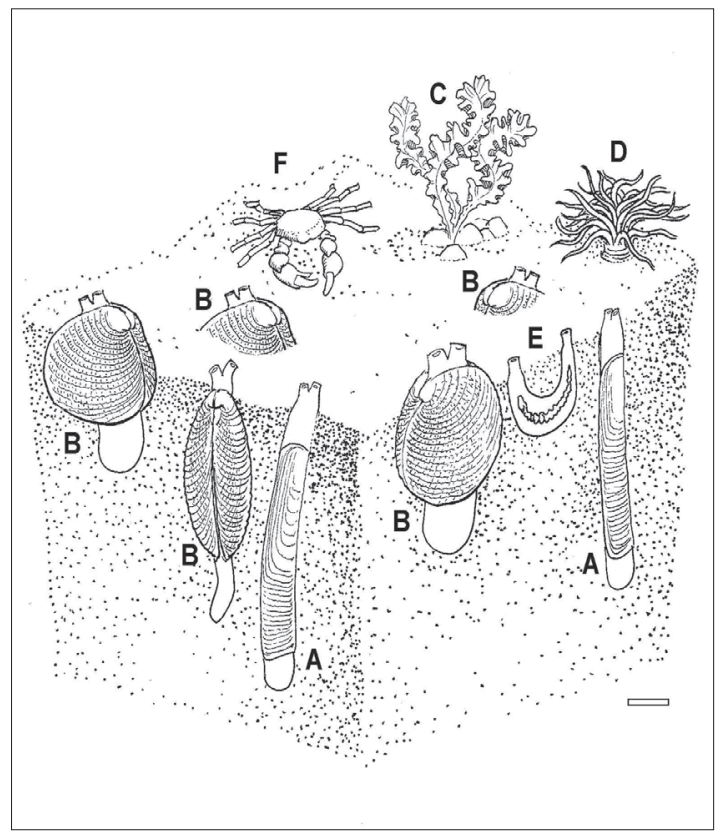

FIG. 4. Reconstruction of the Venus-Ensis paleocommunity based on the fossil record and soft bottom modern communities in the area. A. Ensis macha; B. Venus antiqua; C. green alga; D. tube-dwelling anemone; E. polychaete tube worm; F. crab. Scale bar $=20 \mathrm{~mm}$. common features on the Beagle Channel seafloor. Variations in faunal composition would mainly be related to differences in substrate types, water depth and sedimentation rates.

These three assemblages were deposited during the 7,000-6,000 yr BP. In the Beagle Channel, measurements of paleotemperatures show a fall in values between 6,500 and 5,000 BP (Obelic et al., 1998). At the Río Varela site, marine waters flooded the present mouth area at $c a .6,200 \mathrm{BP}(6,240 \pm 70$ yr BP; Coronato et al., 1999), thus forming a shallow, low-energy, nearshore environment, strongly influenced by the river input and seasonal ice meltwater (Grill et al., 2002).

It therefore seems that these assemblages were formed during a phase of climatic 'deterioration' which took place during the interval 7,000-6,000 BP, prior to $c a .5,500 \mathrm{BP}$, when paleotemperatures and paleosalinities reached their maximum values for the last 8,000 years (Lamy et al., 2002).

\section{Provenance of mid-Holocene Bivalves}

Pleistocene beaches are not very common in the inner portion of the Beagle Channel due to the erosive effect of the last glaciations (Rabassa et al., 2000). However, fossil records would indicate that the Beagle Channel was occupied by sea water at least once during the Pleistocene (Rabassa et al., 1986; Gordillo, 1990b).

In regard to the provenance of mid-Holocene Venus antiqua and Ensis macha specimens in the Beagle Channel, two alternatives are considered: $\mathbf{1}$. as survivors, they might have evolved from stocks that remained in the region within unglaciated marine refuges during Pleistocene glaciations; or 2. as migrants, they might derive from specimens from northern regions with geographic access to the new habitats formed after the last deglaciation. Although the two alternatives are theoretically possible (see Crame, 1996), the mid-Holocene age of these taxa and their mode of life (i.e., infaunal suspension feeders) make it more plausible that they migrated and colonized the new vacant areas after the first stages of the deglaciation period, in which rapid rates of sedimentation made the environment unsuitable for them. Bathymetrical analysis suggests that these taxa entered the Beagle Channel through constricted waterways which have connections with the open Pacific (Antezana, 1999). Rabassa et al. (1986) suggested that the Holocene sea trans- 
TABLE 2. CHRONOLOGICAL DATA AND PALEONTOLOGICAL CHARACTERIZATION OF 3 HOLOCENE MOLLUSK ASSEMBLAGES COLLECTED FROM THE BEAGLE CHANNEL.

\begin{tabular}{|c|c|c|c|}
\hline Characterization & Bahía Golondrina & Río Varela & Lago Roca \\
\hline Lat., long. & $54^{\circ} 49^{\prime} \mathrm{S}, 68^{\circ} 19^{\prime} \mathrm{W}$ & $54^{\circ} 52^{\prime} \mathrm{S}, 67^{\circ} 11^{\prime} \mathrm{W}$ & $54^{\circ} 48^{\prime} \mathrm{S}, 68^{\circ} 36^{\prime} \mathrm{W}$ \\
\hline Elevation (a.s.1.) & $2,0 \mathrm{~m}$ & $3,0 \mathrm{~m}$ & $6,4 \mathrm{~m}$ \\
\hline Dating method & AMS method & Conventional method & Conventional method \\
\hline $\begin{array}{l}\text { Uncorrected radiocarbon age and } \\
\mathrm{C}^{14} \text { laboratory sample code }\end{array}$ & $\begin{array}{l}6,276 \pm 41 \text { yr BP } \\
\text { (AA 62801; this work) }\end{array}$ & $\begin{array}{l}6,240 \pm 70 \text { yr BP } \\
\text { (Pta. } 7581 ; \\
\text { Coronato et al., 1999) }\end{array}$ & $\begin{array}{l}5,920 \pm 90 \text { yr BP } \\
(\text { AC } 1060 ; \\
\text { Rabassa et al., 1986) }\end{array}$ \\
\hline $\begin{array}{l}\text { Calibrated age } \\
(\text { Calib 5.0*) }\end{array}$ & $6,473 \pm 73$ yr BP & $6,433 \pm 96$ yr BP & $6,097 \pm 112$ yr BP \\
\hline Assemblage type & $\begin{array}{l}\text { Authochtonous } \\
\text { assemblage }\end{array}$ & $\begin{array}{l}\text { Allochtonous } \\
\text { assemblage }\end{array}$ & $\begin{array}{l}\text { Allochtonous } \\
\text { assemblage }\end{array}$ \\
\hline Faunal composition & $\begin{array}{l}\text { Venus antiqua } \\
\text { Ensis macha }\end{array}$ & $\begin{array}{l}\text { Venus antiqua } \\
\text { Retrotapes exalbidus } \\
\text { Trophon geversianus } \\
\text { Xymenopsis muriciformis }\end{array}$ & $\begin{array}{l}\text { Tawera gayi } \\
\text { Retrotapes exalbidus } \\
\text { Mulinia edulis } \\
\text { Mytilus chilensis } \\
\text { Aulacomya atra } \\
\text { Perumytilus purpuratus } \\
\text { Venus antiqua } \\
\text { Hiatella solida } \\
\text { Trophon geversianus } \\
\text { Xymenopsis muriciformis } \\
\text { Pareuthria plumbea } \\
\text { Nacella deaurata }\end{array}$ \\
\hline
\end{tabular}

* Radiocarbon Calibration Program; version 5.0 (www.calib.org) in conjunction with: Stuiver, M.; Reimer, P.J. 1993. Radiocarbon 35: $215-230$.

Calibration dataset: marine04.14c. One sigma set. Delta $\mathrm{R}=221 \pm 40$ (additional shift in regional ${ }^{14} \mathrm{C}$ age).

gression in the Beagle Channel took place through the Murray passage (Fig. 1), a narrow entrance to the Beagle Channel between Navarino and Hoste islands, or perhaps somewhere in another more western position.

At the moment, the two alternatives (Pleistocene survivors or Holocene migrants) are possible since available information cannot be used to discard either of these two hypotheses.

\section{Discussion}

Concerning paleobiogeographic patterns of distribution, the presence of Ensis macha and Venus antiqua in life position suggests that during the mid-Holocene, the Beagle Channel acted as a path for dispersion of these taxa between the Atlantic and the Pacific oceans. As both taxa produce planktonic larvae, this served as their primary agent of dispersal. Such larvae are important because they provide a chance for wide geographic distribution and, as a result, they do not always settle or survive in areas better suited for adult growth; other means of dispersal (i.e., drifting of juveniles or small adults) are therefore likely to be important. However, it is unknown yet if these two taxa can drift.

The opportunity for the larvae of these two taxa to settle in the Beagle Channel during the Holocene could be due to the fact that this channel is a more protected area in comparison with the open sea. On the other hand, Brattström and Johanssen (1983) stated that this kind of environment offers the chance of finding suitable biotopes everywhere, because all kinds of bottom types are found on the shore and in 
deeper water, and there is no reason to believe that species will not find suitable bottoms somewhere within the spreading range of the larvae.

Evidence also suggests that both Ensis macha and Venus antiqua probably migrated to the Beagle Channel from northern adjacent areas or deeper waters after deglaciation, entering the channel from the Pacific Ocean via restricted waterways. However, the possibility that these taxa survived the glacial advances within Pleistocene refuges cannot be ruled out.

The analysis of records of Ensis macha and Venus antiqua through time and their geographic links to ecological factors such as their reproductive strategies, showed that both taxa are typical elements of the cold-temperate seas throughout the Magellan Region, exhibiting a similar range of distribution and paleodistribution.

A considerable number of mollusk taxa share the same area of distribution with Ensis macha and Venus antiqua in both oceans. This results in a similar taxa composition in both the Atlantic and the Pacific coasts. A reason for this similarity might be the existence of marine pass-ways during Pleistocene interglacial periods.

Scherer et al. (1998) also mentioned that similar richness and taxa composition between the Ross and Weddell seas might be due to the existence of marine pass-ways during Pleistocene ice sheet collapses that enabled biotic interchange between these disjunct Antarctic seas. Based on the fossil records compiled here, it seems that during the Plio-Pleistocene a great exchange of cold-temperate mollusks took place between the Pacific and the Atlantic basins.

Whether the Magellan Strait represents a second migration route for these taxa between the two oceans is still unknown. Available data proves that during the Quaternary period, the Atlantic entrance was opened just after the first Pleistocene glaciation, whereas communication between the Atlantic and the Pacific oceans occurred after the last glaciation (Brambati et al., 1998).

The faunal and climatic changes during the Holocene are just beginning to be understood. For a more complete understanding of Holocene marine paleoenvironments in the Magellan Region, we need to determine whether these local changes can be correlated over a broader regional scale. Regarding glaciations and faunal exclusion in the Beagle Channel, the origin of the Holocene fauna of this critical geographic area is still under discussion. Only on the basis of an integrated cross-disciplinary approach, a better knowledge of the Holocene history of the Beagle Channel will be achieved.

\section{Acknowledgements}

To P. Barón (CENPAT, Argentina), B. Lomovasky (INIDEP, Argentina) and M. Rivadeneira (Universidad Católica de Chile) who provided useful information to the authors. To C.E. Gómez who helped with the drawings. To L. Ortlieb (Centre de Recherche Ilê de France) and C. Valdovinos (Universidad de Concepción) whose comments and suggestions improved the manuscript. This paper was partly supported by the CONICET (PEI 6131 to S.G.). The radiocarbon dating was funded from the project PICT 00067/2002, ANPCYT-FONCYT, to J. Rabassa.

\section{References}

Aguirre, M.L. 2003. Late Pleistocene and Holocene palaeonvironments in Golfo San Jorge, Patagonia: molluscan evidence. Marine Geology 194: 3-30.

Aguirre, M.L.; Negro Sirch, Y.; Richiano, S. 2005. Late Quaternary molluscan assemblages from the coastal area of Bahía Bustamante (Patagonia, Argentina): Paleoecology and paleoenvironments. Journal of South American Earth Sciences 20: 13-32.

Aguirre, M.L.; Richiano, S.; Negro Sirch, Y. 2006. Palaeoenvironments and palaeoclimates of the Quaternary molluscan faunas from the coastal area of Bahía Vera-Camarones (Chubut, Patagonia). Palaeogeography, Palaeoclimatology, Palaeoecology 229: 251-286.

Aitken, A. 1990. Fossilization potential of Arctic fjord and continental shelf benthic macrofaunas. In Glacimarine Environments: Processes and Sediments (Dowdeswell, J.A.; Scourse, J.D.; editors). Geological Society of London Special Publication 53: 155-176.

Antezana, T. 1999. Hydrographic features of Magellan and Fuegian inland passages and adjacent Subantarctic waters. Scientia Marina 63 (Supl. 1): 23-34.

Avellanal, M.H.; Jaramillo, E.; Clasing, E.; Quijón, P.; Contreras, H. 2002. Reproductive cycle of the bivalves Ensis macha (Molina, 1872) (Solenidae), Tagelus dombeii (Lamarck, 1818) (Solecurtidae) and Mulinia edulis (King, 1831) (Mactridae) in southern Chile. The Veliger 45: 33-44.

Barón, P.J.; Real, L.E.; Ciocco, N.F.; Ré, M.E. 2004. Morphometry, growth and reproduction of an Atlantic population of the razor clam Ensis macha (Molina, 1782). Scientia Marina 68: 211-217.

Beu,A.G. 2004. Marine Mollusca of oxygen isotope stages of the last 2 million years in New Zealand. Part 1: Revised generic positions and recognition of warmwater and cool-water migrants. Journal of the Royal Society of New Zealand 44 (2): 111-265. 
Brambati, A.; De Muro, S.; Di Grande, A. 1998. Marine and transitional Holocene terraces in the eastern area of the Straits of Magellan, Chile. Bollettino di Geofisica Teorica ed Applicata 39: 47-76.

Brattström, H.; Johanssen,A. 1983. Ecological and regional zoogeography of the marine benthic fauna of Chile. Sarsia 68: 289-339.

Carcelles, A. 1944. Catálogo de los moluscos marinos de Puerto Quequén. Revista del Museo Argentino de Ciencias Naturales, Sección Zoología 3: 233-309.

Cárdenas-Mancilla, J.; Gordillo, S. 2006. Paleoambientes marinos del Holoceno de Tierra del Fuego. Un análisis comparativo en base a su malacofauna. In Congreso Argentino de Paleontología y Bioestratigrafía, No. 9, Actas: 60 p. Córdoba.

Cionchi, J.L. 1987. Depósitos marinos cuaternarios de Bahía Bustamante, Provincia del Chubut. Revista de la Asociación Geológica Argentina 42: 61-72.

Clasing, E.; Brey, T.; Otead, R.; Navarro, J.; Asencio, G. 1994. Population dynamics of Venus antiqua (Bivalvia: Veneracea) in the Bahía de Yaldad, Isla de Chiloé, Southern Chile. Journal of Experimental Marine Biology and Ecology 177: 171-186.

Coronato, A.J.; Rabassa, A.; Borromei, M.; Quatroccio and Bujalesky, G. 1999. Nuevos datos sobre el nivel relativo del mar durante el Holoceno en el Canal Beagle, Tierra del Fuego, Argentina. In Congreso Argentino de Geomorfología y Cuaternario, No. 1, Actas: 27-28. Santa Rosa.

Crame, J.A. 1996. Evolution of high-latitude molluscan faunas. In Origin and evolutionary radiation of the Mollusca (Taylor, J.D.; editor). Oxford University Press: 119-131. Oxford.

Del Río, C.; Martínez, S.; Reichler, V. 1998. Moluscos Miocenos de la Argentina y del Uruguay. Academia Nacional de Ciencias, Monografía 15: 1-151.

Di Gerónimo, S.; Privitera, S.; Valdovinos, C. 1991. Molluskan thanatocoenoses of the Magellan Straits. Memorie di Biologia Marina e di Oceanografia 19: 505-508.

Escofet, A.; Orensanz, J.M.; Oliver, S.R.; Scarabino, V. 1978. Benthic studies of the Gulf of San Matías (Río Negro, Argentina): methodology, experiences and results of the ecological studies in a large geographic area in Latin America. Anales del Centro del Ciencias Marinas y Limnología, UNAM 5 (1): 59-81. México.

Feruglio, E. 1950. Descripción Geológica de La Patagonia. Ministerio de Industria y Comercio de La Nación. Dirección General de Yacimientos Petrolíficos Fiscales 3: 1-431.

Figueiras, A. 1967. Contribución al conocimiento de los moluscos marinos del Holoceno uruguayo. Comunicaciones de la Sociedad Malacológica del Uruguay 2: 61-76.

Frassinetti, D. 1997. Moluscos del Plioceno Superior Marino de Isla Guafo, Sur de Chile. Parte I. Bivalvia.
Boletín del Museo Nacional de Historia Natural de Chile 46: 55-79.

Gordillo, S. 1990a. Malacofauna de los niveles marinos holocenos de la Península Ushuaia y alrededores (Canal Beagle, Argentina). In Reunión de Campo de Geología del Cuaternario, No. 3, Resúmenes: 24-25. Bahía Blanca.

Gordillo, S. 1990b. Presencia de Limopsis marionensis Smith, 1885 (Mollusca: Bivalvia) en el Pleistoceno Superior de Tierra del Fuego. In Congreso Geológico Argentino, No. 11, Actas 3: 219-221. San Juan.

Gordillo, S. 1992. Tafonomía y paleoecología de moluscos bivalvos del Holoceno del Canal Beagle, Tierra del Fuego. Tesis Doctoral (Unpublished), Universidad Nacional de Córdoba: 1-286.

Gordillo, S. 1999. Holocene molluscan assemblages in the Magellan region. Scientia Marina 63 (Supl. 1): 15-22.

Gordillo, S.; Bujalesky, G.; Pirazzoli, P.A.; Rabassa, J.O.; Saliege, J.F. 1992. Holocene raised beaches along the northern coast of the Beagle Channel, Tierra del Fuego, Argentina. Palaeogeography, Palaeoclimatology, Palaeoecology 99: 41-54.

Gordillo, S.; Coronato, A.; Rabassa, J. 1993. Late Quaternary evolution of a subantarctic paleofjord, Tierra del Fuego. Quaternary Science Reviews 12: 889-897.

Gordillo, S.; Coronato, A.; Rabassa, J. 2005. Late Quaternary micromollusc assemblages from the southernmost tip of South America: a paleoenvironmental history after the Last Glacial Maximum. Reports on Polar and Marine Research 507: 58-62.

Grill, S.; Borromei, A.M.; Quattrocchio, M.; Coronato, A.; Bujalesky, G.; Rabassa, J. 2002. Palynological and sedimentological analysis of recent sediments from Río Varela, Beagle Channel, Tierra del Fuego, Agentina. Revista Española de Micropaleontología 34: 145-161.

Guzmán, N.; Marquardt, C.; Ortlieb, L.; Frassinetti, D. 2000. La malacofauna Neógena y Cuaternaria del área de Caldera $\left(27-28^{\circ} \mathrm{S}\right)$ : especies y rangos bioestratigráficos. In Congreso Geológico Chileno, No. 9, Actas 1: 476-481. Puerto Varas.

Guzmán, N.; Saá, N.; Ortlieb, L. 1998. Catálogo descriptivo de los moluscos litorales (Gastropoda y Pelecypoda) de la zona de Antofagasta, $23^{\circ} \mathrm{S}$, Chile. Estudios Oceanológicos 17: 17-86.

Heusser, C.J. 1989. Late Quaternary vegetation and climate of Tierra del Fuego. Quaternary Research 31: 396-406.

Heusser, C.J. 1998. Deglacial paleoclimate of the American sector of the Southern Ocean: Late Glacial-Holocene records from the latitude of Canal Beagle $\left(55^{\circ} \mathrm{S}\right)$, Argentine Tierra del Fuego. Palaeogeography, Palaeoclimatology, Palaeoecology 141: 277-301.

Isla, F.; Bujalesky, G.; Coronato A. 1999. Procesos estuarinos en el canal Beagle, Tierra del Fuego. 
Revista de la Asociación Geológica Argentina 54 (4): 307-318.

Kaplan, M.; Ackert, R.; Singer, B.; Douglass, D.; Kurz, M. 2004. Cosmogenic nuclide chronology of millenialscale glacial advances during $\mathrm{O}$-isotope stage 2 in Patagonia. Geological Society of America Bulletin 116: 308-321.

Kappner, I.; Bieler, R. 2006. Phylogeny of venus clams (Bivalvia: Venerinae) as inferred from nuclear and mitochondrial gene sequences. Molecular Phylogenetics and Evolution 40: 317-331.

King, P.P.; Broderip, W.J. 1832. Description of the Cirripeda, Conchifera and Mollusca in a collection formed by the officies of HMS Adventure and Beagle employed between the years 1826 and 1830 in surveying the southern coasts of South America including the Straits of Magellan and the Coast of Tierra del Fuego. Zoological Journal 5: 332-349.

Lamy, F.; Rulemán, C.; Hebbeln, D.; Wefer, G. 2002. High-and low-latitude climate control on the position of the southern Perú-Chile Current during the Holocene. Paleoceanography 17 (2): 1-10.

Lasta, M.; Ciocco, N.; Bremec, C.; Roux, A. 1998. Moluscos bivalvos y gasterópodos. In $\mathrm{El}$ mar Argentino y sus recursos pesqueros. Instituto Nacional de Investigación y Desarrollo Pesquero (INIDEP): 115-142. Mar del Plata.

Lozada, E.; Bustos, H. 1984. Madurez sexual y fecundidad de Venus antiqua (King and Broderip, 1835) en la Bahía Ancud(Molusco: Bivalvia: Veneridae). Revista de Biología Marina 20 (2): 91-112.

Molina, G.L. 1782. Saggio sulla storia naturale del Chili: 367 p. Bologna.

Obelic, B.; Álvarez, A.; Argullós, J.; Piana, E.L. 1998. Determination of water palaeotemperature in the Beagle Channel (Argentina) during the last $6000 \mathrm{yr}$ through stable isotope composition of Mytilus edulis shells. Quaternary of South America and Antarctic Peninsula 11: 47-71.

Ortlieb, L.; Ghaleb, B.; Hillaire-Marcel, C.; Machare, J.; Pichet, P. 1991. Geocronología de terrazas en la costa sur-peruana: Enfoque metodológico. In Congreso Peruano de Geología, No. 7. Resúmenes Extendidos: 511-516. Lima.

Ortlieb, L.; Guzmán, N.; Candia, M. 1994. Moluscos litorales del Pleistoceno Superior en el área de Antofagasta, Chile: Primeras determinaciones e indicaciones paleoceanográficas. Estudios Oceanológicos 13: 57-63.

Ortlieb, L.; Guzmán, N.; Marquardt, C. 2003. A LongerLasting and Warmer Interglacial Episode During Isotopic Stage 11: Marine Terrace Evidence in Tropical Western Americas. American Geophysical Union. Geophysical Mongraph 137: 157-180.

Osorio, C.; Atria, J.; Mann, S. 1979. Moluscos marinos de importancia económica en Chile. Biología Pesquera 11: 3-47.

Osorio, C.; Frassinetti, D.; Bustos, E. 1983. Taxonomía y Morfometría de Venus antiqua (King y Broderip,
1835) (Mollusca, Bivalvia, Veneridae). Tethys 11: 49-56.

Pastorino, G. 1989. Lista preliminar de moluscos cuaternarios de algunos yacimientos de Río Negro y Chubut, Argentina. Comunicaciones de la Sociedad Malacológica del Uruguay (56-57): 129-137.

Pastorino, G. 2000. Asociaciones de moluscos de las terrazas marinas cuaternarias de Río Negro y Chubut, Argentina. Ameghiniana 37: 131-156.

Porter, S.; Stuiver, M.; Heusser, C.J. 1984. Holocene sea-level changes along the Strait of Magellan and Beagle Channel, southernmost South America. Quaternary Research 22: 59-67.

Rabassa, J.O.; Heusser, C.; Rutter, N. 1986. New data on Holocene sea transgression in the Beagle Channel: Tierra del Fuego, Argentina. Quaternary of South America and Antarctica Peninsula 4: 291-309.

Rabassa, J.; Coronato, A.; Bujalesky, G.; Salemme, M.; Roig, C.; Meglioli, A.; Heusser, C.; Gordillo, S.; Roig, F.; Borromei, A.; Quattrocchio, M. 2000. Quaternary of Tierra del Fuego, Southernmost South America: an updated review. Quaternary International 68-71: 217-240.

Ramorino, L. 1968. Pelecypoda del fondo de la Bahía Valparaíso. Revista de Biología Marina 13 (3): 175285.

Reid, D.; Osorio, C. 2000. The shallow-water marine mollusca of the Estero Elefantes and Laguna San Rafael, southern Chile. Bulletin of the Natural History Museum of London, Zoology 66: 109-146.

Richards, H.G.; Craig, J.R. 1963. Pleistocene sedimentation and fauna of the Argentine shelf. II. Pleistocene mollusks of the continental shelf of Argentina. Proceedings of the Academy of Natural Sciences of Philadelphia 115: 127-152.

Ríos, C.; Mutschke, E.; Morrison, E. 2003. Biodiversidad bentónica en el estrecho de Magallanes, Chile. Revista de Biología Marina y Oceanografía 38: 1-12.

Ríos, E. 1994. Seashells of the Brazil. Editora da Fundação Universidade do Rio Grande: 368 p. Brazil.

Scherer, R.P.; Aldahan, A.; Tulaczyk, S.; Possnert, G.; Engelhardt, H.; Kamb, B. 1998. Pleistocene collapse of the West Antarctic Ice Sheet. Science 281 (373): 82-85.

Stuardo, J. 1964. Distribución de los moluscos marinos litorales en Latinoamérica. Boletín del Instituto de Biología Marina de Mar del Plata 7: 79-91.

Stuiver, M.; Reimer, P.J. 1993. Extended ${ }^{14} \mathrm{C}$ database and revised Calib radiocarbon calibration program, Radiocarbon 35: 215-230.

Urban, H.J. 1994a. Adaptations of six infaunal bivalve species of Chile: coexistence resulting from differences in morphology, burrowing depth and substrate preferences. Archive of Fishery and Marine Research 42: 183-195.

Urban, H.J. 1994b. Upper temperatura tolerante of ten bivalve species of Peru and Chile related to El Niño. Marine Ecology Progress Series 107: 139-145.

Urban, H.J. 1996. Population dynamics of the bivalves 
Venus antiqua, Tagelus dombeii and Ensis macha from Chile at $36^{\circ} \mathrm{S}$. Journal of Shellfish Research 15 (3): 719-727.

Urban, H.J.; Tesch, C. 1996. Aspects of the population dynamics of six bivalve species from southern Chile. Archive of Fishery and Marine Research 44: 243-256.

Urien, C.M. 1968. Edad de algunas playas elevadas en la Península de Ushuaia y su relación con el ascenso costero postglaciario. In Jornadas Geológicas Argentinas No. 3, Actas 2: 35-41. Buenos Aires.

Valdovinos, C. 1996. Evolutive stasis of a benthic community during the retraction of the Magellan Province: Analysis of an assemblage of organisms with hard skeletons from the Plio-Pleistocene and recent limits. Reports on Polar and Marine Research 190: 82-84.

Valdovinos, C.; Navarrete, S.; Marquet, P.A. 2003. Mollusk species diversity in the Southeastern Pacific: why are there more species towards the pole? Ecography 26: 139-144.

Verdinelli, M.A.; Schuldt, M. 1976. Consideraciones preliminares sobre aspectos de la dinámica poblacional y reproducción de la almeja rayada Ameghinomya antiqua (King, 1831) (Chionidae) en Punta Loma, Golfo Nuevo-Chubut. Revista del Museo de La Plata 12: 183-202.

Manuscript received: November 09, 2006; accepted: October 28, 2007. 